\title{
CHROMOSOME EVOLUTION IN LOLIUM
}

\author{
H. REES and G. H. JONES * \\ Department of Agricultural Botany, \\ University College of Woles, Aberystwyth
}

\section{INTRODUCTION}

Received 23.iii.66

IT is generally agreed that the divergence and diversity of species during their evolution depend mainly on differences originating in nuclear genetic material; more specifically, on changes in chromosomal deoxyribonucleic acid (DNA). Two main kinds of DNA changes may be involved. The first is qualitative and the second quantitative. Qualitative differences have in some instances been directly observed in the nuclear DNA of different genotypes. For example, DNA base ratios while being constant from tissue to tissue within genotypes (Chargaff and Lipshitz, I953), have been shown to vary between genotypes of different species (Zamenhoff, r952; Belozersky, 196r). There is evidence also of a qualitative variation of a different kind, namely in the order of bases in the nucleic acid, RNA in this case, of virus strains of different genotype (Reddi, I959). Quantitative variation in nuclear DNA is of course common in cases of numerical chromosome change such as polyploidy. It is found also, however, even between diploid species of the same genus (Sunderland and McLeish, r96r; McLeish, r962; Rees et al., r966).

Estimates of quantitative variation in nuclear DNA have in recent years been made mainly by cytochemical methods involving measurements of the amount of Feulgen stain in individual nuclei. The development of these methods permit of a fairly rapid analysis of nuclear DNA amounts in different organisms. Use has been made of these techniques in the present work on Lolium species. The aim, briefly, was to determine whether differences in nuclear DNA amounts are associated with the divergence of the Lolium species. A survey was made of six species within the genus. Subsequently a more detailed investigation was carried out in two of the species and amongst their hybrids and hybrid derivatives. In view of the differences observed an attempt was made to relate the DNA variation to variation in chromosome size and nuclear dry mass. Finally, data are described which relate to the origin and nature of the DNA variation and the consequences of this variation upon the plant phenotype.

\section{MATERIAL AND METHODS}

(a) Material

The genus Lolium comprises a number of species which show considerable diversity with regard to their morphology, habit and breeding systems (table $\mathrm{r}$ ). The.

* Present address: The Genetics Department, University of Birmingham. 
species fall into two well defined groups, the self-pollinating species which are annual in habit and the cross-pollinating species which include biennials and perennials.

TABLE I

The Species. All the seed was obtained from the Welsh Plant Breeding Station

\begin{tabular}{|c|c|c|}
\hline Species & Habit & Mating system \\
\hline $\begin{array}{l}\text { L. perenne } \\
\text { L. multiflorum } \\
\text { L. rigidum } \\
\text { L. temulentum } \\
\text { L. remotum } \\
\text { L. loliaceum }\end{array}$ & $\begin{array}{l}\text { Perennial } \\
\text { Biennial } \\
\text { Winter annual } \\
\text { Annual } \\
\text { Annual } \\
\text { Annual }\end{array}$ & $\begin{array}{c}\text { Outbreeding } \\
,, \\
\text { ", } \\
\text { Inbreeding } \\
,, \\
,,\end{array}$ \\
\hline
\end{tabular}

All are diploids with 14 chromosomes (Darlington and Wylie, 1955; Jenkin and Thomas, 1938). The chromosome morphology of all the species is very similar, and corresponding chromosomes in the different species are in general identifiable although not identical (Thomas, 1937; Malik, 1964).

\section{(b) Methods}

\section{(i) Estimation of nuclear $D \mathcal{N} A$ by Feulgen microspectrophotometry}

The fixation and staining technique used was that described in detail by McLeish and Sunderland (196I) and Sunderland and McLeish (196I). Photometric measurements were made on a Barr and Stroud Integrating microdensitometer. All measurements were made on $2 C$ telophase and early interphase nuclei.

\section{(ii) Estimation of nuclear dry mass by microscope interferometry}

Measurements of total nuclear dry mass were made by interference microscopy, the theory of which is described by Barer (1956) and by Davies (1958). Calculations of the dry mass of isolated nuclei were based on optical path differences measured with a Baker interference microscope, using the equation

$$
\text { Mass }=\frac{\text { Area } \times p . d .}{100 x} .
$$

The optical path differences (p.d.) were measured at $543 \mu$ with a half-shade eyepiece attachment. An average value for $x$ of o-oor 8 was used (see Barer $o p$. cit.). The areas were calculated from measurements obtained using a micrometer eyepiece with an accurate vernier scale. The masses of the nucleolar regions and the rest of the nucleus were calculated separately and then summed to give the total nuclear dry mass.

Root tip nuclei were isolated according to the procedure described by McLeish (1963) except that a press was found unnecessary, the nuclei being readily freed by tapping the root tips with the flattened end of a glass rod.

\section{(iii) Estimation of Chromosome Volumes}

For calculating the chromosome volumes the total chromatid length was measured at metaphase in each cell by means of a micrometer eyepiece and a mean estimate of chromatid width obtained from a random sample of five chromatids per cell. The calculation of the total chromosome volume assumes each chromatid to be cylindrical in form which, although not strictly true, is a convenient and reasonable approximation. Metaphases were scored in root tips following colchicine treatment and Feulgen staining. 


\section{RESULTS}

(a) Nuclear DNA Variation in the Six Lolium Species

While the chromosome number is constant $(2 n=14)$ the size of chromosomes differs considerably between the species. In particular the three inbreeding species considered have larger chromosomes than the outbreeders (Thomas, I937; Naylor and Rees, 1958; Malik, 1964).

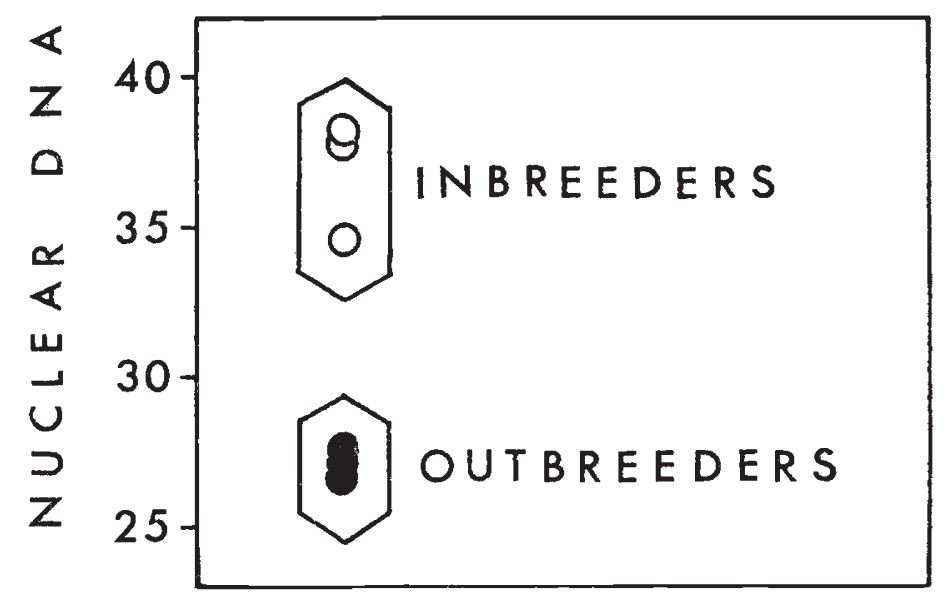

FIc. 1. - Nuclear DNA values (in arbitrary units) in the inbreeding and outbreeding Lolium species.

These observations suggest the possibility of a variation in nuclear DNA amount. This possibility was confirmed; the inbreeders, $L$. temulentum, $L$. remotum and $L$. loliaceum, have, on average, 36 per cent. more nuclear DNA than the outbreeders L. perenne, L. multiflorum and L. rigidum (table 2$)$. The difference is highly significant $(\mathrm{P}<0 \cdot 00 \mathrm{r})$.

TABLE 2

Mean DNA amounts (in arbitrary units) in ${ }_{2} \mathrm{C}$ nuclei of six Lolium species (estimates are based on ten nuclei in each case)

\begin{tabular}{|l|l|l|l|}
\hline & \multicolumn{2}{|c|}{ DNA per $2 C$ nucleus } & \\
\cline { 2 - 3 } Species & & \\
& Slide I & Slide II & \\
\hline & & & \\
\hline & & & \\
\hline L. perenne & $27 \cdot 00$ & $27 \cdot 90$ & $27 \cdot 45$ \\
L. italicum & $26 \cdot 80$ & $27 \cdot 60$ & $27 \cdot 20$ \\
L. rigidum & $26 \cdot 30$ & $27 \cdot 00$ & $26 \cdot 65$ \\
L. temulentum & $37 \cdot 30$ & $38 \cdot 00$ & $37 \cdot 65$ \\
L. remotum & $37 \cdot 60$ & $38 \cdot 50$ & $38 \cdot 05$ \\
L. loliaceum & $34 \cdot 30$ & $35 \cdot 00$ & $34 \cdot 65$ \\
& & & \\
\hline
\end{tabular}

Thus, divergence and evolution in this diploid genus is achieved or at least accompanied by considerable quantitative variation in nuclear DNA which, in turn, is correlated with change in chromosome size. 
(b) Nuclear variation in L. perenne, L. temulentum, their hybrids and hybrid derivatives

(1) Chromosome size

The total chromatid lengths, breadths and estimated volumes in five metaphases of $L$. perenne, $L$. temulentum and their $F_{1}$ are given in table 3 (see also fig. 2). With respect to volume, which is likely to be the best measure of size, we note the following:-

I. On average the total volume of $L$. temulentum chromosomes exceeds that of $L$. perenne chromosomes by approximately 40 per cent.

2. The total chromosome volumes calculated from hybrid cells are roughly intermediate between the parental values.

TABLE 3

Chromosome size in cells of $\mathrm{L}$. perenne, $\mathrm{L}$. temulentum and the $\mathrm{F}_{1}$ hybrid

\begin{tabular}{|c|c|c|c|c|}
\hline & Cells & $\begin{array}{c}\text { Total } \\
\text { chromosome } \\
\text { length }(\mu)\end{array}$ & $\begin{array}{l}\text { Average } \\
\text { chromatid } \\
\text { width }(\mu)\end{array}$ & $\begin{array}{l}\text { Total } \\
\text { chromosome } \\
\text { volume }\left(\mu^{3}\right)\end{array}$ \\
\hline \multirow[t]{2}{*}{ L. perenne } & $\begin{array}{l}1 \\
2 \\
3 \\
4 \\
5\end{array}$ & $\begin{array}{l}48 \cdot 65 \\
49 \cdot 54 \\
53 \cdot 27 \\
52 \cdot 58 \\
51 \cdot 27\end{array}$ & $\begin{array}{l}0.55 \\
0.58 \\
0.57 \\
0.58 \\
0.57\end{array}$ & $\begin{array}{l}23 \cdot 29 \\
26 \cdot 08 \\
26 \cdot 77 \\
27 \cdot 68 \\
25 \cdot 75\end{array}$ \\
\hline & Mean & $5^{1 \cdot 06}$ & 0.57 & $25 \cdot 9^{I}$ \\
\hline \multirow[t]{2}{*}{ L. temulentum } & $\begin{array}{l}1 \\
2 \\
3 \\
4 \\
5\end{array}$ & $\begin{array}{l}69 \cdot 27 \\
67 \cdot 75 \\
64 \cdot 17 \\
69 \cdot 69 \\
66 \cdot 72\end{array}$ & $\begin{array}{l}0.5^{8} \\
0.59 \\
0.62 \\
0.5^{8} \\
0.59\end{array}$ & $\begin{array}{l}35 \cdot 69 \\
37 \cdot 50 \\
38 \cdot 97 \\
36 \cdot 69 \\
36 \cdot 80\end{array}$ \\
\hline & Mean & $67 \cdot 52$ & 0.59 & $37 \cdot 13$ \\
\hline \multirow[t]{2}{*}{ L. per. $\times$ L. tem. } & $\begin{array}{l}\text { I } \\
2 \\
3 \\
4 \\
5\end{array}$ & $\begin{array}{l}54 \cdot 37 \\
60 \cdot 44 \\
6 r \cdot 62 \\
56 \cdot 79 \\
59 \cdot 82\end{array}$ & $\begin{array}{l}0.5^{8} \\
0.57 \\
0.57 \\
0.5^{8} \\
0.5^{8}\end{array}$ & $\begin{array}{l}28 \cdot 63 \\
31 \cdot 83 \\
30 \cdot 96 \\
29 \cdot 4^{1} \\
3^{2} \cdot 75\end{array}$ \\
\hline & Mean & $5^{8 \cdot 6 I}$ & $0 \cdot 5^{8}$ & $3^{0 \cdot} \cdot 7^{2}$ \\
\hline
\end{tabular}

The differences in chromosome volume are attributable almost entirely to differences in chromosome length; the widths differ very little. The indication is that the degree of coiling of metaphase chromosomes at mitosis is fairly consistent for the three genotypes. 

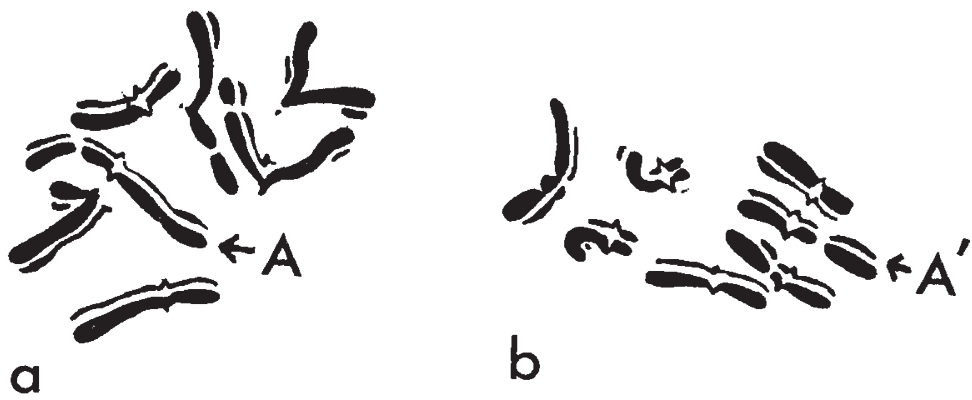

b

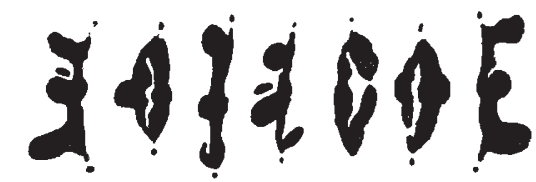

C
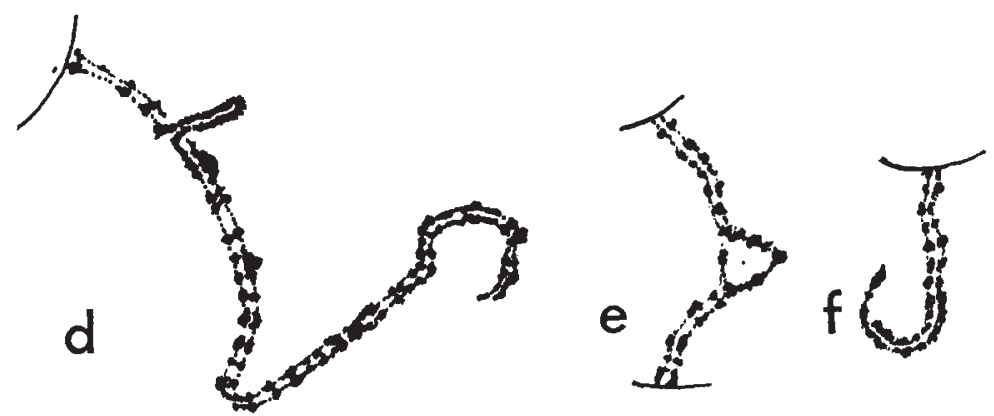

FIG. 2.- $a, b$. The haploid complements of $L$. temulentum and L. perenne at the first pollen grain mitosis $\times c a .2$ 1 oo. c. First metaphase of meiosis in a p.m.c. of the $F_{1}$ (L. perenne $\times L$. temulentum). Note asymmetry with regard to all seven bivalents. $\times$ ca. I 300. d.e.f. Unpaired loops and ends at pachytene in the $F_{1}$.

(ii) Nuclear dry mass

Measurements of the dry mass of isolated $2 C$ nuclei of both species and their hybrids are given in table 4 . To make sure that the measurements involved ${ }_{2} C$ nuclei a procedure of double selection of the following kind was adopted. Of ten small, presumably ${ }_{2} C$, nuclei scored the mean dry mass was estimated from the five nuclei having the lowest values. From these measurements the following will be observed:-

I. The dry mass of $L$. temulentum nuclei is approximately 37 per cent. greater than that of $L$. perenne nuclei.

2. The nuclear dry mass values of ${ }_{2} C$ hybrid nuclei are intermediate between the parental values.

Table 4 also shows that the dry mass of the nucleolus in relation to the total dry mass of the nucleus is the same not only for the two parent 
species but also for the $F_{1}$. In terms of quantity at least the $F_{1}$ is as effective in producing nucleolar material as are the two parent genotypes.

\section{TABLE 4}

Mean dry mass values of ${ }_{2} \mathrm{C}$ nuclei in two plants each of $\mathrm{L}$. perenne,

L. temulentum and their $\mathrm{F}_{1}$ hybrid

\begin{tabular}{|c|c|c|c|c|c|}
\hline & & \multicolumn{4}{|c|}{ Dry mass values ( $\left.\times 10^{-11} \mathrm{gm}.\right)$} \\
\hline & & Nucleolus & $\begin{array}{l}\text { Rest of } \\
\text { nucleus }\end{array}$ & $\begin{array}{c}\text { Total } \\
\text { nucleus }\end{array}$ & $\begin{array}{l}\text { Nucleolus/ } \\
\text { Total }\end{array}$ \\
\hline \multirow[t]{2}{*}{ L. perenne } & $\begin{array}{l}1 \\
2\end{array}$ & $\begin{array}{l}0.91 \\
0.83\end{array}$ & $\begin{array}{l}2 \cdot 54 \\
2 \cdot 52\end{array}$ & $\begin{array}{l}3 \cdot 45 \\
3 \cdot 35\end{array}$ & - \\
\hline & Mean & $0 \cdot 87$ & $2 \cdot 53$ & $3 \cdot 40$ & 0.26 \\
\hline \multirow[t]{2}{*}{ L. temulentum } & $\begin{array}{l}1 \\
2\end{array}$ & $\begin{array}{l}1 \cdot 03 \\
1 \cdot 27\end{array}$ & $\begin{array}{l}3 \cdot 5^{6} \\
3 \cdot 4^{8}\end{array}$ & $\begin{array}{l}4 \cdot 59 \\
4 \cdot 75\end{array}$ & - \\
\hline & Mean & $1 \cdot 15$ & 3.52 & $4 \cdot 67$ & $0 \cdot 25$ \\
\hline \multirow[t]{2}{*}{ L. per. $\times$ L. tem. } & $\begin{array}{l}1 \\
2\end{array}$ & $\begin{array}{l}1 \cdot 02 \\
1 \cdot 13\end{array}$ & $\begin{array}{l}3 \cdot 03 \\
3 \cdot 21\end{array}$ & $\begin{array}{l}4^{\cdot 05} \\
4^{\cdot} 34\end{array}$ & - \\
\hline & Mean & $1 \cdot 07$ & $3 \cdot 12$ & $4 \cdot 19$ & 0.26 \\
\hline
\end{tabular}

(iii) DNA amounts

Table 5 gives the mean nuclear DNA values of ten plants each of $L$. perenne and $L$. temulentum and also of five $F_{1}$ hybrid plants. The data also appear in the histograms in fig. 3. An analysis of variance

TABLE 5

$D \mathcal{N} A$ amounts in ${ }_{2} \mathrm{C}$ nuclei of $\mathrm{L}$. perenne, L. temulentum and their $\mathrm{F}_{1}$ hybrid. Each value is derived from measurements of ten nuclei in each plant

\begin{tabular}{|c|c|c|c|c|c|c|c|c|c|c|c|}
\hline & \multicolumn{11}{|c|}{ DNA amount per ${ }_{2} C$ Nucleus (in arbitrary units) } \\
\hline & \multicolumn{10}{|c|}{ Plant } & \multirow{2}{*}{ Mean } \\
\hline & 1 & 2 & 3 & 4 & 5 & 6 & 7 & 8 & 9 & 10 & \\
\hline $\begin{array}{l}\text { L. perenne } \\
\text { L. temulentum } \\
\text { L. per. } \times \text { L. tem. }\end{array}$ & $\begin{array}{l}30 \cdot 8 \\
41 \cdot 4 \\
35 \cdot 6\end{array}$ & $\begin{array}{l}31 \cdot 4 \\
42 \cdot 3 \\
37 \cdot 0\end{array}$ & $\begin{array}{l}3^{1} \cdot 6 \\
4^{2 \cdot 0} \\
3^{6 \cdot 2}\end{array}$ & $\begin{array}{l}30 \cdot 7 \\
4 I \cdot 6 \\
3^{6 \cdot 0}\end{array}$ & $\begin{array}{l}32 \cdot 0 \\
41 \cdot 6 \\
37 \cdot 4\end{array}$ & $\begin{array}{l}31 \cdot 6 \\
42 \cdot 8 \\
-\end{array}$ & $\begin{array}{l}31 \cdot 2 \\
42 \cdot 6 \\
-\end{array}$ & $\begin{array}{l}3^{1 \cdot 0} \\
4^{1 \cdot 8} \\
-\end{array}$ & $\begin{array}{l}31 \cdot 0 \\
42 \cdot 4 \\
-\end{array}$ & $\begin{array}{l}31 \cdot 8 \\
42 \cdot 6 \\
-\end{array}$ & $\begin{array}{l}31 \cdot 3 \\
42 \cdot 1 \\
36 \cdot 8\end{array}$ \\
\hline
\end{tabular}


confirms that the nuclear DNA variation between "genotypes" is highly significant $(\mathrm{P}<0.00 \mathrm{I})$. We also note the following:-

I. L. temulentum has approximately 35 per cent. more DNA per ${ }_{2} C$ nucleus than $L$. perenne, as shown by the earlier data.

2. The DNA content of hybrid ${ }_{2} C$ nuclei is intermediate between the parental values.

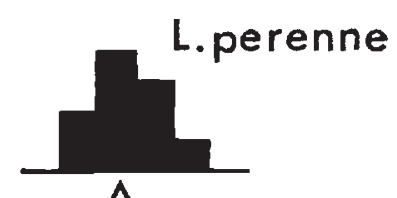

L. temulentum
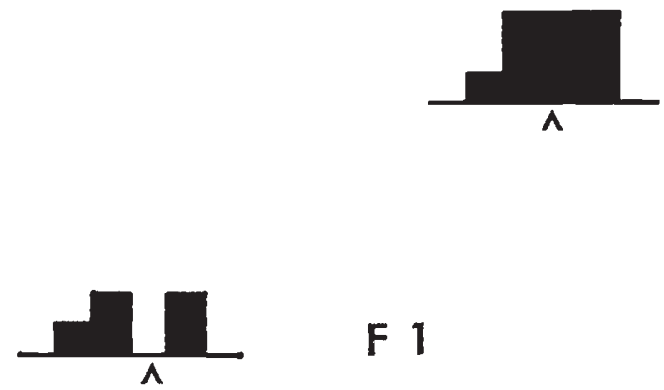

F 1

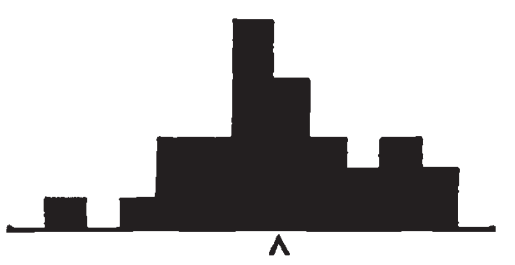

Backcross
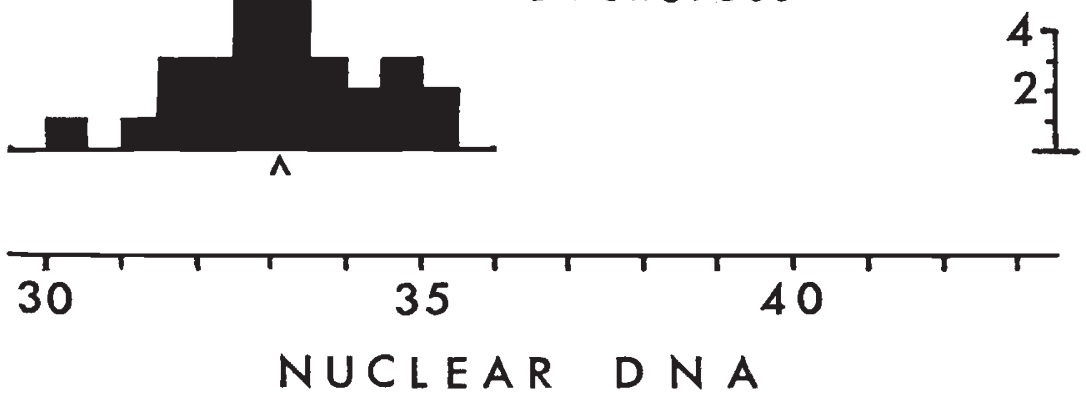

Fig. 3.-The distributions of nuclear DNA values (arbitrary units) in two Lolium species, their $F_{1}$ and backcross derivatives (see text).

(iv) Chromosome size, nuclear mass and $D \mathcal{N} A$ content

Table 6 summarises the data described above. From it we note that:-

I. The relationship between nuclear DNA and chromosome volume is consistent for all three genotypes (cf. Darlington, 1965). From this it may be inferred that, with respect to the density of DNA, the organisation of chromosomes is similar in all three forms.

2. The DNA/dry mass ratio also is constant throughout. It follows that the DNA component in relation to other nuclear 
components is consistent for the three genotypes and that these components vary proportionately.

3. The relation between nuclear dry mass and chromosome volume shows a similar constancy, which in turn implies a similarity in the density and hence, presumably, in the overall structural organisation of the nuclear material in both parent species and in their $F_{1}$.

TABLE 6

The relationship between mean nuclear $D \mathcal{N} A$, chromosome volume and dry mass

\begin{tabular}{|c|c|c|c|c|c|c|}
\hline Type & $\begin{array}{c}\text { DNA } \\
\text { content }\end{array}$ & $\begin{array}{l}\text { Chromosome } \\
\text { volume }\end{array}$ & $\begin{array}{c}\text { Nuclear } \\
\text { dry } \\
\text { mass }\end{array}$ & $\begin{array}{l}\text { DNA/ } \\
\text { chromosome } \\
\text { volume }\end{array}$ & $\begin{array}{l}\text { DNA/ } \\
\text { dry } \\
\text { mass }\end{array}$ & $\begin{array}{c}\text { Dry mass/ } \\
\text { chromosome } \\
\text { volume }\end{array}$ \\
\hline $\begin{array}{l}\text { L. perenne } \\
\text { L. temulentum } \\
F_{1}\end{array}$ & $\begin{array}{l}3 I \cdot 3 \\
42 \cdot I \\
3^{6} \cdot 8\end{array}$ & $\begin{array}{l}25 \cdot 9 \\
37 \cdot 1 \\
30 \cdot 7\end{array}$ & $\begin{array}{l}3.40 \\
4.67 \\
4.19\end{array}$ & $\begin{array}{l}I \cdot 28 \\
I \cdot I 3 \\
I \cdot 20\end{array}$ & $\begin{array}{l}9 \cdot 2 \\
9 \cdot 0 \\
8 \cdot 8\end{array}$ & $\begin{array}{l}0 \cdot 13 \\
0 \cdot 13 \\
0 \cdot 14\end{array}$ \\
\hline
\end{tabular}

For all three measurements the $\mathrm{F}_{1}$ hybrid gives intermediate values. While this result is not in itself surprising it may nevertheless be interpreted in one of two very different ways.

(a) Irreversible structural variation. Given that the greater size and mass of $L$. temulentum as compared with $L$. perenne chromosomes reflect permanent, irreversible difference in basic structure then the combination of larger, L. temulentum, and smaller, L. perenne, chromosomes in the $F_{1}$ hybrid will give intermediate values such as are found above.

(b) Genotypically controlled variation. Chromosome form or phenotype is determined not only directly by its permanent structural components but may also, indirectly, be influenced by the action of nuclear genes. Such genes may effect changes in mechanical organisation or even, it may be envisaged, in the chemical composition of chromosomes. On this basis it could be supposed for example that the action of a gene or genes accounts for the larger chromosomes of L. temulentum as compared with $L$. perenne. If this were so then the intermediate chromosome size recorded in the $F_{1}$ would be quite easily explained were the genes determining the difference between the two species to be additive in effect and to show no dominance in the heterozygous $F_{1}$.

From the data presented so far it is not possible to distinguish with certainty between the two alternatives above. The distinction can readily be made, however, with further information on the chromosomes of the hybrid. If the first, structural, explanation applies then the size difference between the chromosomes of the two species will be maintained in the hybrid. With overall genotypic control it will not. Relevant data for these Lolium species and their hybrid with respect to chromosome size have already been presented by Naylor 
and Rees (1958). The lengths * of particular chromosomes, $A$ of $L$. temulentum and $A^{\prime}$ of $L$. perenne were measured in nuclei of the parent species and in $F_{1}$ nuclei. These are summarised in fig. 4. It will be observed that the size difference between the chromosomes is maintained in the hybrid nuclei and hence a structural basis established for the variation.

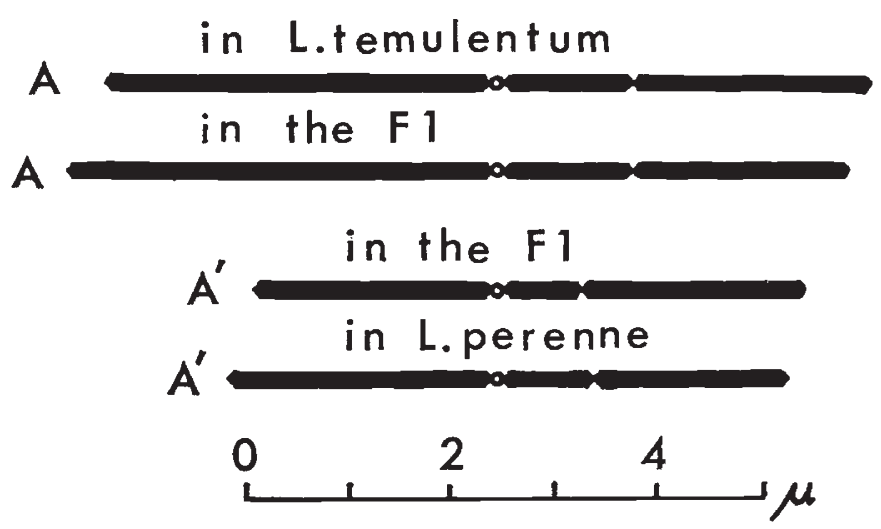

FIG. 4.-Chromosomes $A$ of $L$. temulentum and $A^{\prime}$ of $L$. perenne in the parental and hybrid nuclei respectively. Estimates of length are based on ten cells in each instance. Note that the size difference between $A$ and $A^{\prime}$ is maintained in the hybrid.

The distinction between the longer and slightly thicker L. temulentum chromosomes as compared with those of L. perenne is also clearly evident at meiosis in the $F_{1}$ hybrid (fig. 2 and plate figs. $c, d$ ). The asymmetry with respect to size applies to all seven bivalents, showing that the chromosomal changes associated with the divergence of these species are widespread throughout the nucleus.

\section{(c) The basis of change}

There are two main possibilities to consider in relation to the established differences in chromosome structure. The first is that the extra chromosome material in L. temulentum is the result of longitudinal duplication of chromosome parts. The second possibility is that increased polynemy (see Darlington, I966; Lewis and John, I963) accounts for the increased mass of the $L$. temulentum chromosomes. The distinction matters not only in respect of the origin of change but also with respect to its genetic consequences. Lengthwise duplication of parts involves duplication of some loci, whereas variation in strandedness or polynemy involves duplication or replication of all loci (see Rees et al., I966).

Convincing evidence of lengthwise duplication comes from observations of pachytene in the $F_{1}$ hybrid (see fig. 2 and plate fig. $e$ ). Incomplete pairing at the ends of the pachytene associations and in interstitial regions, with frequent unpaired loops, testify to a widespread duplication.

* Since, as already described, the widths of chromosomes are fairly constant in this material the length measurements provide a reliable index of size. 
Whether such duplication accounts completely for the variation cannot, as yet, be established with certainty. For this purpose a more detailed pachytene analysis is desirable in order to ascertain whether the pairing anomalies extend to the 30 per cent. or so required to account entirely for the chromosome differences. The possibility of a difference in polynemy cannot, in the meantime, be discounted. What is certain is that to a considerable degree the structural variation is the result of lengthwise duplication.

\section{(d) The Phenotypic Consequences}

The kinds of variation in the chromosome phenotype which, so far, have been described are more or less direct consequences of the duplication of chromosome segments. The following is an account of the more indirect consequences of chromosome change upon a wider range of characters, both nuclear and otherwise.

Three aspects of the phenotype have been investigated. These are the behaviour of chromosomes at meiosis, the viability of seedlings and the expression of seedling leaf characters. These investigations are based on observations of parental and $F_{1}$ genotypes and of the progenies of backcrosses between the $F_{1}$ hybrid and $L$. perenne.

\section{(i) Meiosis: Chromosome pairing and chiasma formation}

The parent species. From fig. 5 it will be seen that the inbreeder, $L$. temulentum, has a considerably higher chiasma frequency per pollen mother cell (p.m.c.) than the outbreeder L. perenne. This, in view of the longer chromosomes of $L$. temulentum, is not surprising. It is well known that, in general, chiasma frequency increases with chromosome length (Mather, 1938).

The $F_{1}$. The loop formation and other manifestations of incomplete pairing at pachytene would lead us to expect irregularities in chiasma formation and in chromosome pairing at first metaphase. This, precisely, is what one finds. Univalents, for example, are far more common in $F_{1}$ than in either of the parent species. All I $5 F_{1}$ plants showed univalents as compared with six out of ${ }_{5} 5$ plants of $L$. perenne and none of the $L$. temulentum plants. Furthermore an average of 17 per cent. of p.m.c. in the $F_{1}$ plants carried univalents as compared with only 8.5 per cent. in those $L$. perenne plants with univalents.

While univalents are common in $F_{1}$ p.m.c. the average chiasma frequencies of the $F_{1}$ plants are not lower than those in the $L$. perenne plants (fig. 5). It is of course quite probable that these $F_{1}$ chiasma frequencies would be higher were it not for the restriction on pairing imposed by structural heterozygosity. Data from the backcross progeny to be described later fully support this view. But on the basis of the $F_{1}$ data alone, one of the consequences of the structural heterozygosity is quite clear, namely the irregular distribution of chiasmata between bivalents. This is revealed in the hybrid not only by the high univalent frequency. From fig. 6 it will also be seen that for com- 
parable chiasma frequencies bivalents with an unusually high number of chiasmata, three and four, as well as univalents, are far more common in the hybrid than in the parental p.m.c.
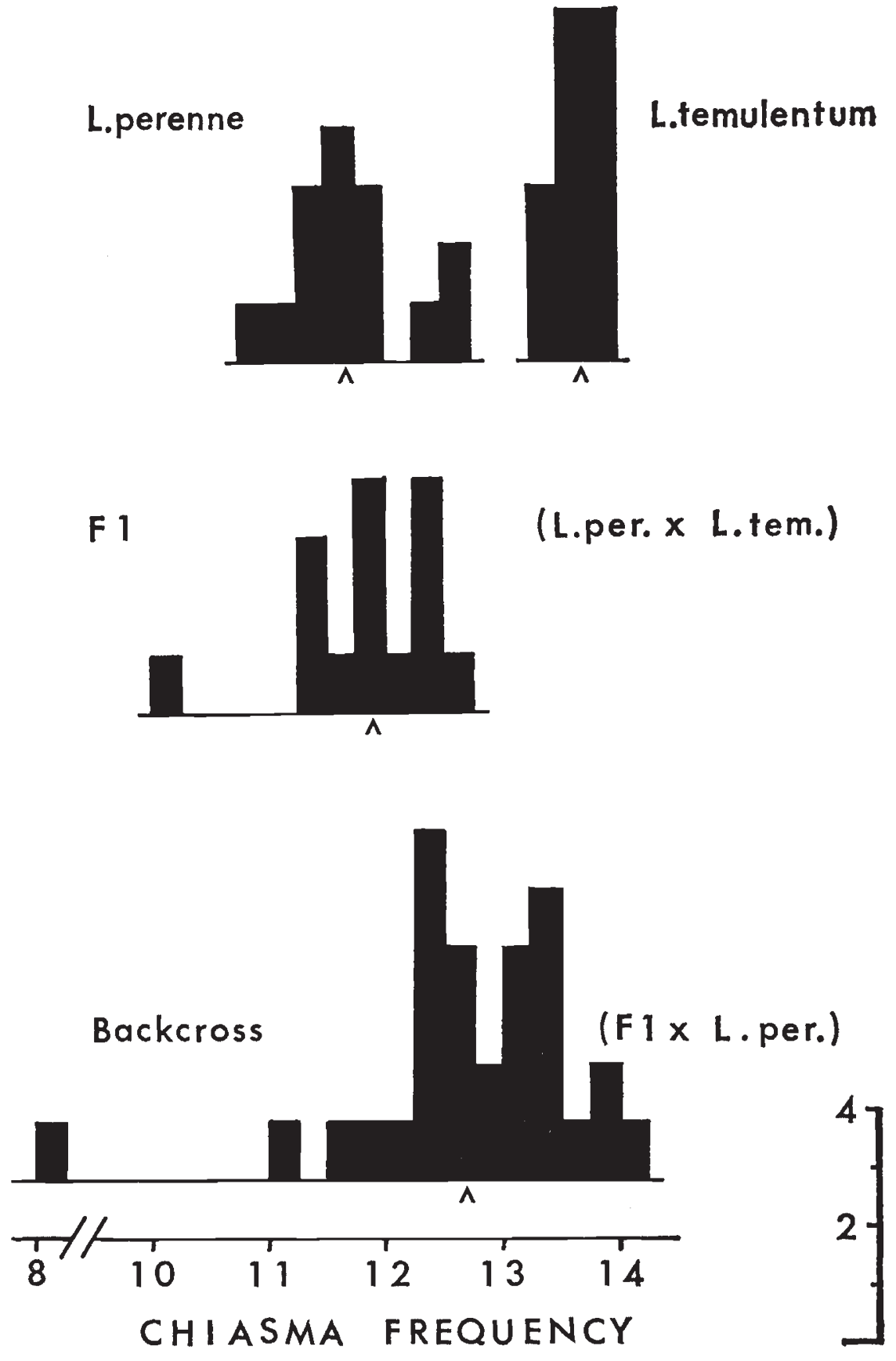

FIG. 5.-The chiasma frequency distributions (as averages per p.m.c. per plant) in parent, $F_{1}$ and backcross progenies. Note the increased mean chiasma frequency of the backcross as compared with the $F_{1}$. 


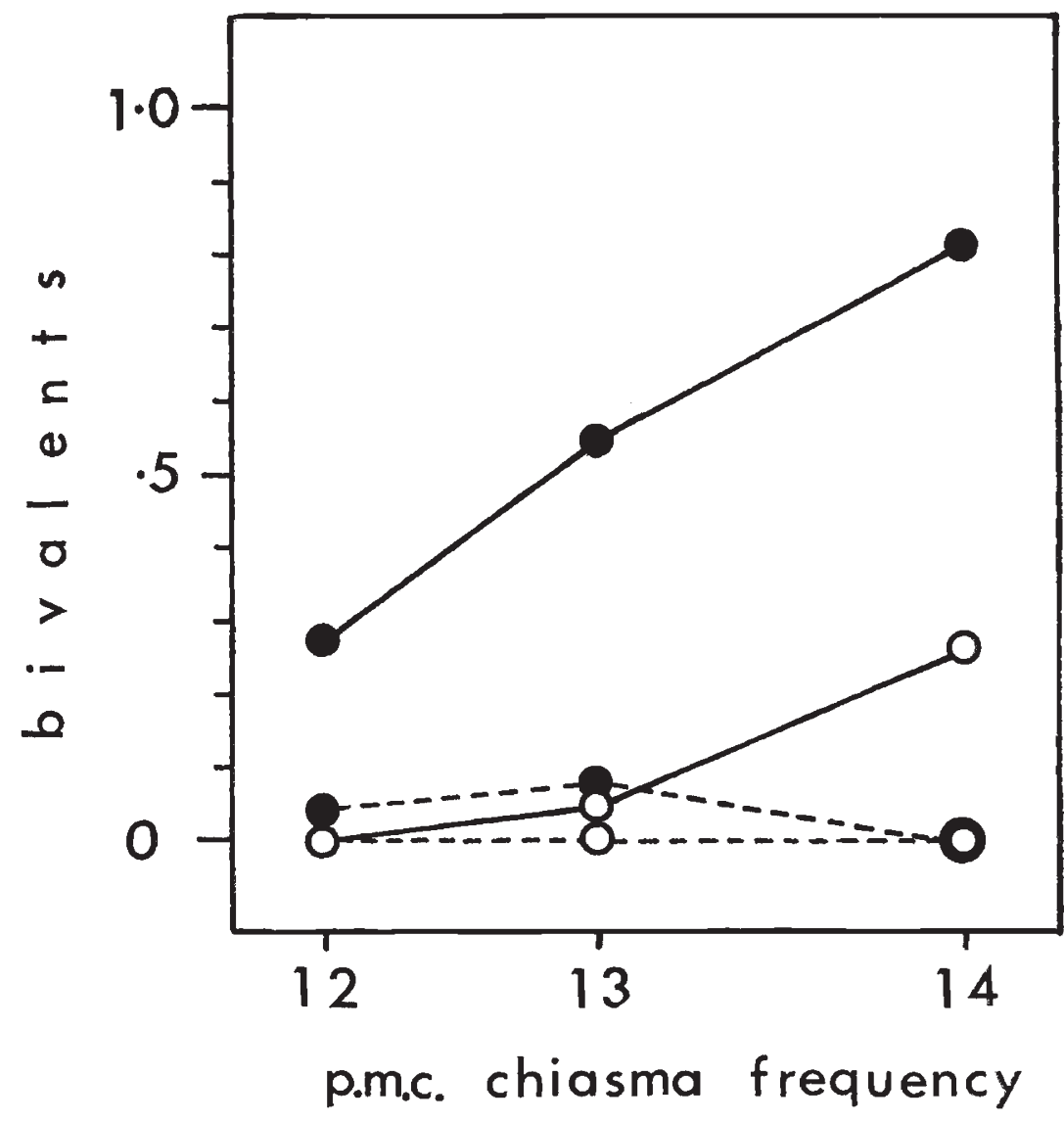

Fig. 6.-The average number of bivalents with three or more chiasmata (solid line) and of pairs of univalents (dotted line) in p.m.c. of the parents (open circles) and of the $F_{1}$ (closed circles). Bivalents with three or more chiasmata as well as univalents are commoner in the $F_{1}$ p.m.c. than parent p.m.c. of corresponding chiasma frequencies. (Data from parent species were similar and hence pooled.)

The backcross. It has been assumed that the irregularity of meiosis in $F_{1}$ is mainly explained by the structural differences between $L$. temulentum and L. perenne chromosomes. As a result of backcrossing these structural differences will decrease by approximately a half. In consequence it would be expected that chromosome pairing and chiasma formation would be more complete and regular in the backcross individuals than in the $F_{1}$. Both expectations are confirmed by the analysis of the backcross data which are presented in fig. 5. First, the proportion of plants with univalents is lower in the backcross (30 per cent.). Second, the average chiasma frequency per plant is considerably and significantly higher $(\mathrm{P}<\mathrm{O} \cdot \mathrm{OI})$ in the backcross generation $(12 \cdot 7)$ than in $F_{1}$ ( I I.9).

These backcross data, while confirming the expectations consequent upon the reduction of chromosome structural heterozygosity, also indicate a genotypically determined variation superimposed upon that 
determined by chromosome structure. The evidence for this are the transgressive chiasma frequencies among backcross plants. One for example has a mean chiasma frequency of $8 \cdot I$, much lower than that found in any plant of $L$. perenne, the parent with the lower chiasma frequency. Similarly, one of the backcross plants has a chiasma frequency higher $\left(I^{\circ} \mathbf{I}\right)$ than any found among $L$. temulentum plants.

\section{(ii) Survival and selection}

Following segregation and the recombination of the L. temulentum and $L$. perenne chromosomes in $F_{1}$ the expectation on backcrossing is that the progeny will show nuclear DNA values ranging between that of the $F_{1}$ and the $L$. perenne parent and that the distribution of these values would be of a continuous and normal form with a mean and mode intermediate between that of the $F_{1}$ and $L$. perenne values. Both expectations assume that backcross individuals with different nuclear DNA values have equal chances of survival. The DNA estimates made in the backcross progeny are plotted in fig. 3. The mean nuclear DNA content of these plants is $33 . \mathrm{I}$, approximately intermediate between that of the $F_{1}$ and $L$. perenne values ( $36 \cdot 8$ and $3 \mathrm{I} \cdot 3$ respectively). Further, the distribution of backcross DNA values shows no sign of skewness or of pronounced kurtosis. Both observations indicate that under the experimental conditions of germination and growth there is no differential selection with respect to survival.

\section{(iii) The expression of seedling characters}

It is reasonable to suppose that some of the phenotypic differences between $L$. perenne and $L$. temulentum are in part at least determined by genetic differences associated with the variation in nuclear DNA amount between the two species. To test for this possibility the expression of three seedling characters was scored and related to nuclear DNA amounts in the backcross individuals. If it can be shown that the phenotype tends towards that of L. perenne in plants with low nuclear DNA and towards that of $L$. temulentum in plants with high nuclear DNA content then it may be concluded that the genetic differences underlying the variation are to some degree associated with the differences in DNA. The three characters are listed below.

I. Area of the fifth leaf.

2. Days to the emergence of the sixth leaf.

3. Tiller number after 40 days.

Between the parent species there are appreciable differences in respect of all three characters. L. perenne has a smaller leaf area, a slower rate of leaf emergence and tillers more rapidly and freely than L. temulentum. If with low nuclear DNA values the seedling phenotype tends towards that of $L$. perenne the expectation is a positive correlation between both leaf area and days of leaf emergence with DNA 
amount and a negative correlation between tiller number and nuclear DNA. The data are plotted in fig. 7. Regression analyses of variance of these data gave the following results:-

I. The expected positive correlation between leaf area and nuclear DNA amount is not significant $(\mathrm{P}>0.2)$.

2. The expected positive correlation between days to leaf emergence and nuclear DNA is significant at the 5 per cent. level.

3. The expected negative correlation between tiller number and nuclear DNA is significant at the 5 per cent. level.

From these results there is good evidence therefore that the DNA amount per nucleus in backcross individuals, reflecting as it does the relative contribution of genetic material from the two parent species, is correlated with the expression of continuously varying characters which distinguish the two species. More precisely, the indications are that the extra DNA in L. temulentum either incorporates genes affecting tillering and the rate of leaf emergence or, alternatively, is linked with such genes. It is implicit also that such genes are either dominant to their allelic counterparts in $L$. perenne or, if no such allelic forms occur, are not suppressed by other genes in the $L$. perenne complement. In this connection the fact that no significant association is found between DNA amount and the other seedling character, leaf area, in the backcross plants need not necessarily mean that no genes controlling this character are embodied in or associated with the extra DNA of $L$. temulentum. They could be recessive or hypostatic to genes of the $L$. perenne complement. One further point emerges from these backcross results. That the segregation with regard to the seedling characters and to tiller number is of a continuous nature shows that many genes are involved, that these genes are not closely linked and that they are in fact widespread throughout the complement. This fits perfectly well with the earlier finding that the extra DNA, with which these genes appear to be associated, is distributed widely throughout the $L$. temulentum complement.

\section{CONCLUSIONS}

In this diploid genus as in others (Rees et al., I966), the divergence and evolution of the species is associated with a considerable change in nuclear DNA amount. It is certain that in part at least the change stems from lengthwise duplication or replication of chromosome segments. Whether the DNA changes may also come about in other ways, e.g. by lateral variation in a polynemic chromosome organisation, cannot be resolved from the information available to date. It is worth emphasising that the changes are widespread throughout the chromosome complement. The extra 30 per cent. or so nuclear DNA is distributed between all seven $L$. temulentum chromosomes as revealed 

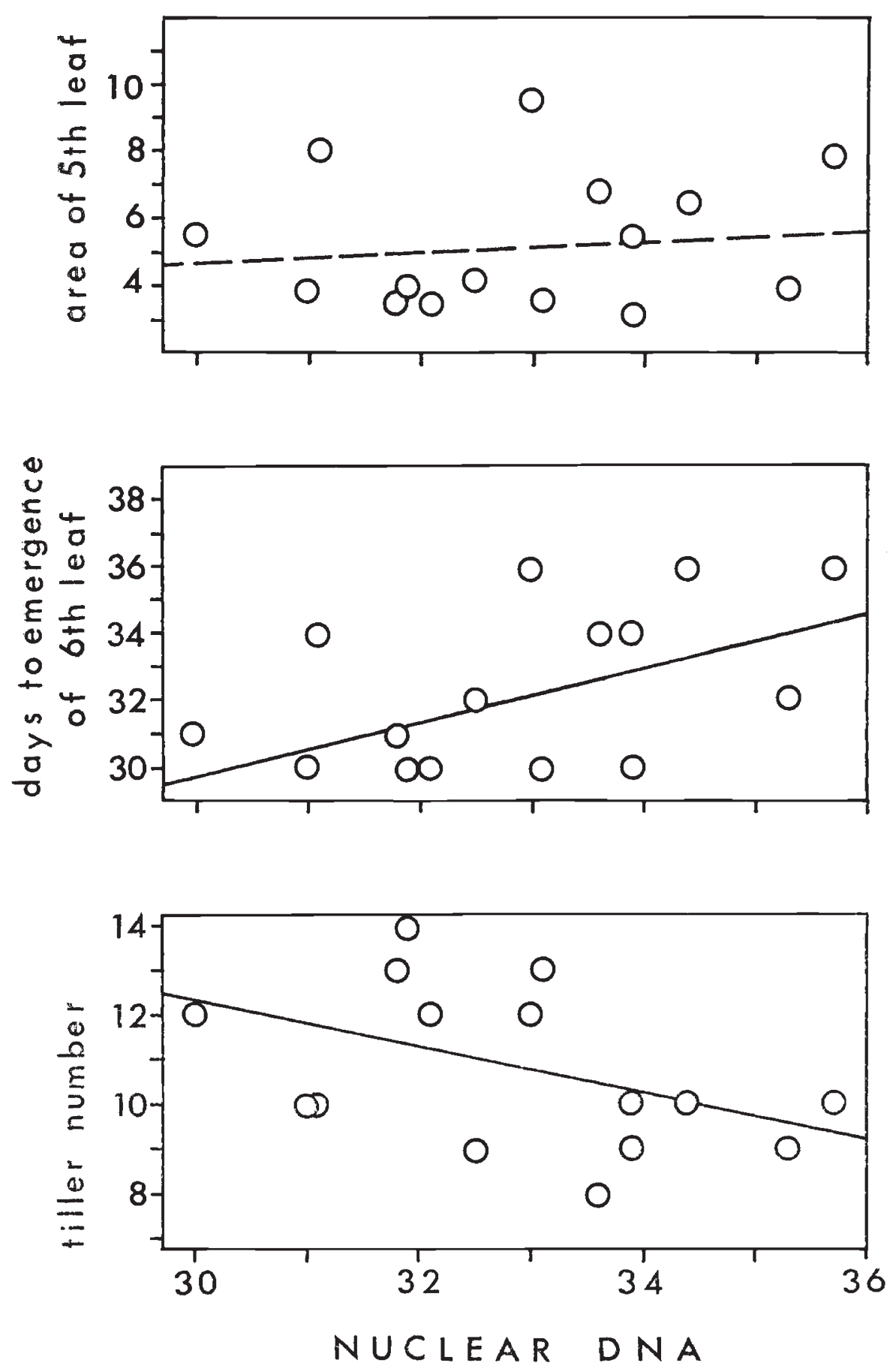

FIG. 7.-The expression of three morphological characters in backcross seedlings plotted against the nuclear DNA amounts of the seedlings (see text). 
by comparison with the $L$. perenne complement in the species hybrid described (fig. 2). It is tempting to suggest that a DNA increase of this high order could be tolerated in no other way. It is well known from the study of polysomics whether in man (Lejeune et al., 1959) or in the thorn apple (Blakeslee, 1922) that replication restricted to one or few chromosomes within a complement results in severe genetic unbalance with consequent reduced fitness and viability. The spreading of the extra genetic material throughout the whole complement in Lolium may well be the result, therefore, of selective elimination of genotypes where the increased DNA is distributed other than in a symmetrical fashion amongst the chromosomes. Clearly it will be of interest to inquire into the nature of the distribution of extra genetic material between species in other diploid genera.

As to the general consequences of the nuclear changes described, these are both varied and extensive. One surprising feature is that the two species, L. temulentum and L. perenne, despite the large differences in the DNA content of their nuclei, still show such close genetic affinity in that they are readily hybridised and that the hybrid produced is not only vigorous in development but also comparatively fertile (see Jenkin and Thomas, 1938). As mentioned earlier this could be taken to indicate that the extra DNA is ineffective or " uninformative", not necessarily because it is largely inert but perhaps because much of its information simply duplicates that already present. It would of course be rash to suppose that the accumulation of all this extra DNA during the evolution of these species was of minor significance to the plant phenotype. Indeed the analysis carried out among backcross individuals derived from a species cross showed that some of the heritable and, it may be supposed, adaptive variation in seedling characters is closely associated with the nuclear DNA differences and may well be directly determined by it.

Given that adaptive changes result from the increased DNA it is worth considering whether there is any significance in the observation that the increase pertains to the inbreeding as compared with the outbreeding Lolium species. There are, in fact, two good theoretical reasons for expecting the increased DNA in the inbreeding species (cf. Lewis and John, 1963 ).

I. Following longitudinal duplication of a chromosome segment in an inbreeding individual a quarter of the offspring will immediately be homozygous for the duplication. A line can thus be quickly established without the protracted cytological complications of structural heterozygosity.

2. Duplication of genes followed by mutation could give rise to a lateral genic " heterozygosity" and a consequent "internal balance" (Darlington and Mather, I949) with respect to individual chromosomes. In an inbreeding species the resulting "built in " permanent heterozygosity may readily be envisaged as an important adaptive feature. 


\section{Plate I}

Metaphase $I$ in p.m.c. of $a, L$. temulentum, $b, L$. perenne, $c$ and $d$, their $F_{1}$ hybrid (L. perenne $\times L$. temulentum) $\times c a$. $1750, e$, Pachytene in the $F_{1}$ hybrid with impaired regions $(u)$ including loops $(l)$. 


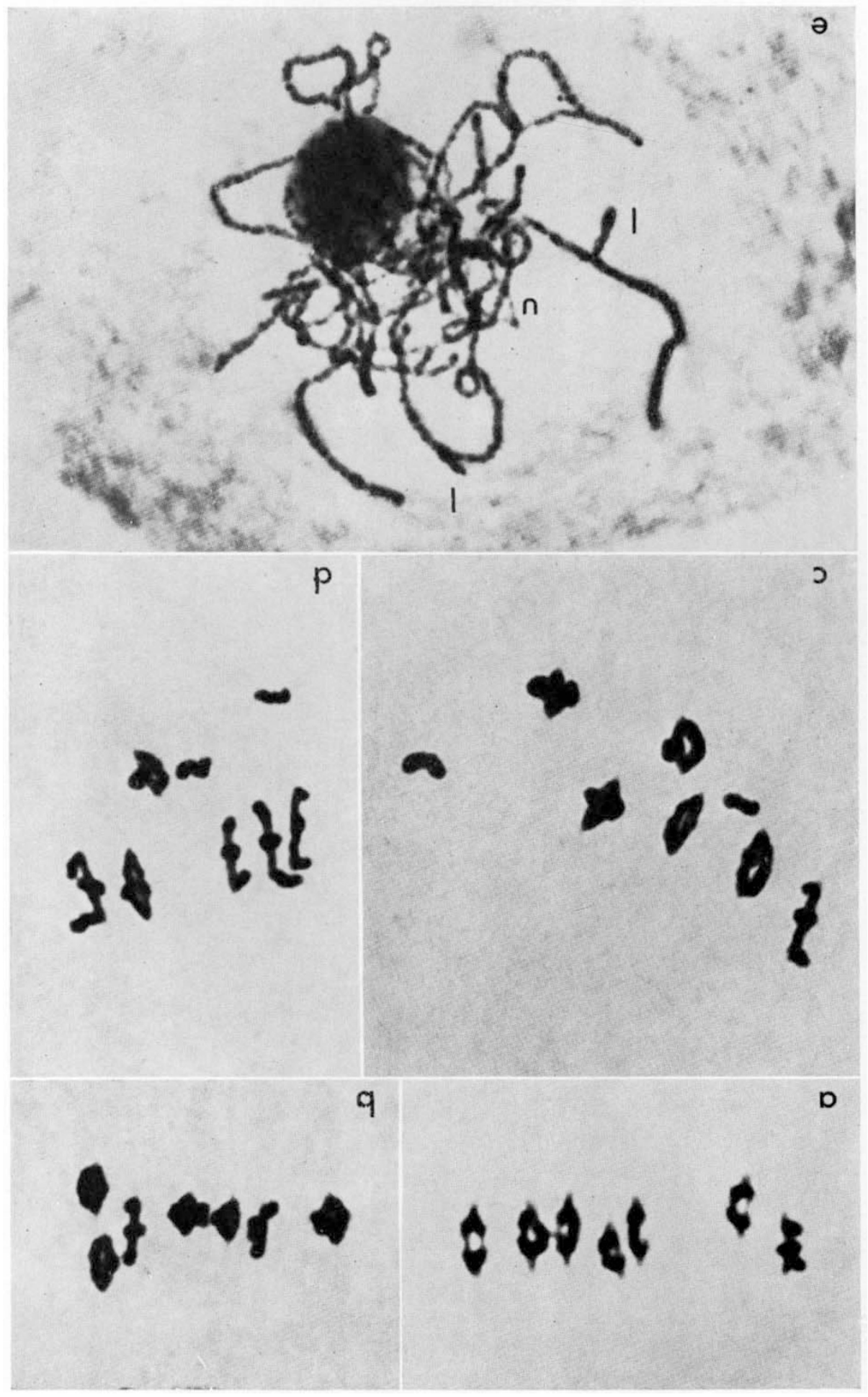


Both these points are necessarily speculative. If they are valid we should expect, for one thing, the increased nuclear DNA in many, even if not all (cf. Rees et al., I 966 ), inbreeding species as compared with related outbreeders.

\section{SUMMARY}

I. The evolution of species within the diploid genus Lolium is associated with variation in nuclear DNA amounts. The nuclear DNA content of three inbreeding species is about 35 per cent. greater than that of three outbreeding species investigated.

2. From a detailed investigation of a representative inbreeder, $L$. temulentum, and of an outbreeder, $L$. perenne, and of their $F_{1}$ hybrid and backcross progeny it was shown that:-

(i) Nuclear DNA content is proportional to chromosome volume and to the nuclear dry mass.

(ii) The DNA variation is in part at least attributable to lengthwise replication of chromosome segments.

(iii) The DNA variation applies to all seven chromosomes of the Lolium complement.

3. The structural differences between $L$. perenne and $L$. temulentum chromosomes cause irregularities in chromosome pairing at pachytene of meiosis in the $F_{1}$. Chiasma formation is irregular and univalents common at first metaphase. The reduction of structural heterozygosity following backcrossing results in an increased chiasma frequency among backcross progeny as compared with $F_{1}$ plants.

4. The distribution of nuclear DNA amounts among the backcross plants shows no evidence of a differential selection affecting the survival of plants with varying nuclear DNA amounts.

5. There is evidence to indicate that the extra nuclear DNA in $L$. temulentum is associated with genes controlling the expression of leaf form and tillering in seedlings.

Acknowledgment.--One of the authors (G. H. Jones) acknowledges the award of an A.R.C. postgraduate studentship.

\section{REFERENCES}

BARER, R. 1956. The interference microscope in quantitative cytology. Supplement to 2nd Ed. The Baker Interference Microscope.

belozersky, A. N. ig6r. The specificity of nucleic acid according to species. Proc. Vth International Congress of Biochemistry Symposium No. III.

BLAKESLEE, A. F. 1922. Variations in Datura due to changes in chromosome number. Amer. Nat., 56, 16-31.

ChARGAFF, E., AND LIPSHITZ, R. 1953. Composition of mammalian deoxyribonucleic acids. 7. Amer. Chem. Soc., 75, 3658 .

DARLington, C. D. 1965. Cytology. London, Churchill. 
Darlington, C. D., AND mather, K. 1949. The Elements of Genetics. London, Allen and Unwin.

DARLington, C. D., AND wYlie, A. P. 1955. Chromosome Atlas of Flowering Plants. London, Allen and Unwin.

DAVIES, H. G. 1958. The determination of mass and concentration by microscope interferometry. General Cytochemical Methods, Vol. I. Academic Press Inc.

JENkin, т. J., AND thomas, P. T. 1938. The breeding affinities and cytology of Lolium species. Fourn. Bot., 76 , 10-12.

LEJEUNE, J., TURPIN, R., AND GAUTIER, M. 1959. Le mongolisme, premier exemple d'aberration autosomique humaine. Ann. Genet. Hum., I, 4 I-49.

LEWIS, K. R., AND John B. 1963. Chromosome Marker. London, Churchill.

MALIK, C. P. 1964. Ph.D. Thesis, University of Wales.

MATHER, K. 1938. Crossing Over. Biol. Rev., 13, 252-292.

MCLEISH, J. 1963. Quantitative relationships between deoxyribonucleic and ribonucleic acid in isolated plant nuclei. Proc. Roy. Soc., B., 158, 261-278.

MCLEISH, J., AND SUNDERLAND, N. 1961. Measurements of deoxyribose nucleic acid (DNA) in higher plants by Feulgen photometry and chemical methods. Exp. Cell Res., 24, 527-540.

NAYLOR, B., AND REES, H. 1958. Chromosome size in L. temulentum and L. perenne. Nature, ${ }_{181}, 854$.

REDDI, K. K. 1959. The arrangement of purine and pyrimidine nucleotides in Tobacco Mosaic Virus nucleic acid. Proc. Nat. Acad. Sci., 45 (3): 293-300.

REes, H., CAMERON, R. M., JONES, G. H., AND hazARIKA, M. H. 1966. Nuclear variation between diploid Angiosperms. Nature, Lond., $2 I I, 828-830$.

SUNDERLAND, N., AND MCLEISH, J. 1961. Nucleic acid content and concentration in root cells of higher plants. Exp. Cell Res., 24, 54 I-554.

Thomas, P. T. 1937. Ph.D. Thesis, University of Wales.

zAMENhofF, s. 1952. Newer aspects of the chemistry of nucleic acids. Phosphorus Matabolism, II. Baltimore, John Hopkins University Press, 301-328. 